\title{
Factors Influencing People's Participation in Home Garden Project during Covid-19 Pandemic: A Review
}

\author{
Siti Rahayu Abdul Aziz ${ }^{1}$, Nurul Hidayah Mat Zain ${ }^{2}$, Nurul Huda Nik Zulkipli ${ }^{3}$, Nor Azylia Ahmad Azam ${ }^{4}$ \\ ${ }^{1,2,3,4}$ Faculty of Computer and Mathematical Sciences,UiTM Cawangan Melaka, Malaysia, \\ 1 rahayu748@uitm.edu.my, ${ }^{2}$ nurul417@uitm.edu.my, ${ }^{3}$ nurulhuda8450@uitm.edu.my, \\ 4azylia@uitm.edu.my
}

\begin{abstract}
The COVID-19outbreak has caused people to live in anxiety and fear. This eing implemented as a preventive measure to halt the COVID-19pandemic. People are forced to stay at home, which causes them stress and boredom. As a result, most people turned to social mediaplatforms and use them actively. One of the current trends during MCO is that people learn how to grow plants in the home garden project. This activity is more exciting with the involvement and of help of social media platformssuch as Facebook. However, to date, only few past studies have discussed the factors influencing social media users' behaviour, mainly Facebook, to involve with the home garden project during MCO.Therefore, this study explored the behavioural intention to use Facebookas a platform to share the information regarding home garden project during MCO. This study applied the extended Unified Theory of Acceptance and Use of Technology (UTAUT) model, which used the original model, focusing on performance expectancy, effort expectancy, social influence and facilitating condition. Then, two new factors, namely perceived enjoyment and cognitive gratification, were integrated to predict primary factors of influencing Facebook user's behaviour to involve with the home garden project during MCO. The research can be used as a guideline to help develop better apps in order to cultivate home garden projects.
\end{abstract}

Key words:Facebook, Home Garden Project, Movement Control Order, COVID-19, UTAUT.

\section{INTRODUCTION}

Malaysia' movement control order, or commonly referred as the MCO, started on March 182020 is a preventive measure in response to the COVID-19 Pandemic. It is also commonly known as a "lockdown" or "partial lockdown". During the MCO, most of the countries are barring its citizens from traveling overseas, no social gatherings allowed, including attending any religious events and shutting all businesses except shops selling food and daily necessities, and in a drastic move to stem a surge in coronavirus infections. The COVID-19 Pandemic has forced millions of people to live under strict lockdown conditions. When people get to stay at home, and no longer free to do their daily routine in an extended period, this ordeal has affected their behavior physically and emotionally. Recently, many research studies relevant to people's behaviour during a pandemic have been conducted to advance the fight against COVID-19.

The long period of lockdown may lead individuals to get bored, mental and emotional distress and live in an unhealthy way. Mental and emotional distress has been identified as a severe problem among the community as they cannot go to work, and to a certain extent, the employersare terminating some of them. The impact of stress also leads to the increase of domestic violence criminal cases.

One of the activities that can be done during MCO is home gardening, which can reduce stress and maintain natural resources, and it alsocan promote self-sufficiency, self-regulation, sustainability, and environmental protection[1]

Hence,the present study highlighted the factors influencing social media, mainly Facebook user's behavior to get involved with the home garden project during MCO.

\subsection{Facebook}

Facebook is one of the most popular social media sites (SNSs) and it was established by Mark Zuckerbergin February 2004. Facebook's features are designed to encourage interaction and communication to keep users connected. Thus, it can be used to share information, socialize and entertain[2],[3],[4]. During $\mathrm{MCO}$, the use ofFacebook is increasing tremendously with more than three billion internet users logged onto Facebook, and the Facebook Live views also have doubled as disclosed by the Facebook CEO, Mark Zuckerberg.

Facebook offers multiple functions in one place which users can share information, knowledge and resources with others. The various Facebook features that are attractive and user-friendly also contribute to promoting users' intentions in using them. Inthis paper [5], the authors discuss Facebook features that may affect user behaviour as shown in Table 1 . 
Social media encourages people's communication processing and decision creation, such as news assessment [6]and newscast selection [7]. Besides, people commonly share content that they think exciting or essential with an intentionto share across social networks and to inspire others' interests [8].

Table 1: Facebook Features

\begin{tabular}{|c|c|}
\hline FacebookFeatures & Descriptions \\
\hline Number of likes & $\begin{array}{l}\text { This feature allows users to seethe number } \\
\text { of "likes" for a post or pageon Facebook. } \\
\text { Post or page with many "likes" indicates } \\
\text { users are interested in that particular post or } \\
\text { page. }\end{array}$ \\
\hline $\begin{array}{l}\text { Friend's } \\
\text { Recommendation }\end{array}$ & $\begin{array}{l}\text { This feature allows users to suggest } \\
\text { something to other Facebook users by } \\
\text { 1. tagging their friends' name in the post. } \\
\text { 2. writing their friends' names in the } \\
\text { comment section. } \\
\text { 3. repost the selected post and } \\
\text { write/mention their friends' name on the } \\
\text { post status }\end{array}$ \\
\hline Comment Posting & $\begin{array}{l}\text { The feature is like writing feedback or } \\
\text { opinion on a specific product or service } \\
\text { after experiencing it. Good comments or } \\
\text { reviews on the product will influence } \\
\text { people to buy the product or } \\
\text { service, whereas bad commentsmay result } \\
\text { in people not buying it. }\end{array}$ \\
\hline Sharing Posting & $\begin{array}{l}\text { The feature allows users to share posts, } \\
\text { pages, products or services that they think } \\
\text { are relevant to them[9]. They can click the } \\
\text { "share" button to share the post that they } \\
\text { are interested in. With that, it will be } \\
\text { available on their page as well as their } \\
\text { friends' newsfeed. }\end{array}$ \\
\hline $\begin{array}{l}\text { Facebook } \\
\text { Advertisement }\end{array}$ & $\begin{array}{l}\text { The Facebook advertisement gives users } \\
\text { the ability to proactively interact with the } \\
\text { adverts, which allows them to "like" and } \\
\text { "share". They also can see their friends or } \\
\text { other Facebook users who have liked or } \\
\text { share the same advertisement[10]. }\end{array}$ \\
\hline $\begin{array}{l}\text { Community } \\
\text { Groups }\end{array}$ & $\begin{array}{l}\text { This feature allows users to create a group } \\
\text { with individuals of the same interest such } \\
\text { as hobbies and activities. It can be created } \\
\text { as a public or a private group. }\end{array}$ \\
\hline Newsfeed & $\begin{array}{l}\text { The newsfeed is a feature where users can } \\
\text { keep updated with friends, family and also } \\
\text { stay informed about the issues that interest } \\
\text { them. Commonly, Facebook newsfeed will } \\
\text { prioritize three (3) criteria which are user's } \\
\text { post, type of contents and interactions with } \\
\text { the post. Newsfeed is based on whose post } \\
\text { which is typically from friends, family, } \\
\text { news resources, business and public } \\
\text { figures. Newsfeed is established using the } \\
\text { type of content produced on most frequent } \\
\text { user's interaction with favoured photos, } \\
\text { videos or links. Onthe other hand, } \\
\text { interactions with the posts that have a lot of } \\
\text { likes, reactions, comments and share also } \\
\text { contribute to the Facebook newsfeed. }\end{array}$ \\
\hline
\end{tabular}

Lamanauskas et al.[11]showed the relationship between social influence and addiction in Facebook use. Their study confirmed that two variables are intercorrelated. Mas'od et al.[5]found that several Facebook features and activities can influence consumers' intention to purchase.Hence, the present study highlights the factors of influencing media social mainly Facebook user's behaviours to get involved with the home garden project during MCO.

\subsection{The Advantage of Home Garden Project}

Gardening is good for health and mind, and humans can still get some of the same benefits even when they are stuck inside because of COVID-19's lockdown movement restriction order. Previous research [12] has shown gardening can improve mental healthand wellbeing[13][14], social connection and happiness. Thus, it can support stress management, reduce stress and fatigue.

\subsubsection{Gardening as a physical activity}

Soga et al.[13]mentioned in their article that practical strength from physical activities can be achieved through gardening. By gardening, physical movements will increase fitness and health in humans. Soga et al.'s study also mentioned, gardeners who spent more than 20 hours per month, on average, engaging with gardening activities reported a lesser sum of health complaints. Soga et al.[15]found that gardening can improve physical, psychological, and social health issues that human are facing nowadays. The authors also encouraged government, policymakers and people to participate in regular exercise by gardening as a beneficial health intervention.

\subsubsection{Gardening promotes peacefulness}

The frustration of enforced confinement because of the Coronavirus someway will increase stress, depression and anxiety. A ton of research tells us that contact with nature has significant health benefits. Gardening allows humans to interact with green spaces boosts physical and mental well-being by about the same amount as getting enough exercise. Wood, Pretty and Griffin investigation had come out with finding that gardening can raise both self-esteem and mood. Other than that gardeners also have a greater life happiness, reduced stress of being alone, less health complaints and better overall mental health[14].

\subsubsection{Gardening promotes family bonding}

COVID-19's lockdown period with family members is the best moment to spend time together doing various bonding activities which will definitely help the individual as well as family development. Gardening is one of the mediums to develop family bonding. As gardening is one of the ways to develop family bonding, family members will be given the responsibility to work on how to ensure the plantsto grow well. Sometimes family members also need to coordinate time to water the plants and manage them to prevent soil compress. 


\section{THEORETICAL BACKGROUND}

Many research works have contributed to the fundamental theories regarding user acceptance of current technologies and applying them in a different context. This section discusses several theories used in proposing a new framework including social influence theory, the unified theory of acceptance and use of technology (UTAUT), use and gratification theory, perceived enjoyment theory and behavioural intention model.

\subsection{TheUnified Theory of Acceptance and Use of Technology (UTAUT) Model}

The UTAUT is developed by Venkatesh et al.[16]. The theory combines the previous alternative views on users and innovation acceptance. The theory was developed after reviewing and integrating eight dominant theories and models as mentioned in William et al.[17]. The dominants contributing theories and models are widely used and utilized by a vast number of previous studies by adopting and diffusing the technology and innovation within multidisciplinary fields [17].

The model of Venkatesh et al.[16]recommends four main core factors that will determine the behavioural intention; 1) performance expectancy, effort expectancy, social influence, and facilitating conditions. Finally, these factors and the behaviour will be moderated by gender, age, experience, and voluntariness of use [16]. Thus, six main variables are proposed in UTAUT: performance expectancy (PE), effort expectancy (EE), social influence (SI), behavioural intention (BI), and usage behaviour (UB), BI is both an independent and dependent variable. The relationship between internal and external variables are measured in [16] as shown in Figure 1.

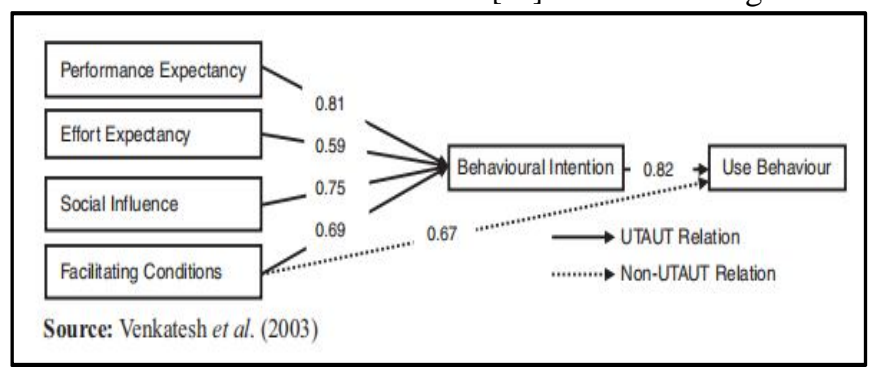

Figure 1: Weight significance among UTAUT core constructs

However, the UTAUT has several limitations as listed in [17] and[18]. Therefore, in this paper, a new model is proposed by extending the UTAUT model by adding other factors which are cognitive gratification and perceived enjoyment.

\subsection{Social Influence Theory}

Social influence on technology acceptance behaviour is widely recognized, however, there is a room for improvement.

In [19], the research proved that social influences is significantly important in the formation of internal motivation to guide the voluntary use of IT for non-work related purposes. The role of this theory has been emphasized by Davis et al.[20]in information technology usage.Moreover, the differences of social influence processes can be used as a groundwork for developing knowledge in this area as suggested by Kelman[21]. This theory has also been established as an important factor driving the intention to use the technology[11][22].

\subsection{Perceived Enjoyment Theory}

Perceived enjoyment was firstly introduced by Davis et al.[23] in the TAM model as internal motivation while perceived usefulness is defined as external motivation. Perceived enjoyment is defined as "the extent to which the activity of using the computer is perceived to be enjoyable in its own right, apart from any performance consequences that may be anticipated' [23].

Base on this assumption, perceived enjoyment has highlighted on the pleasure and internal satisfaction that are derived from the specific activity. Davis et al.[23]also agreed that the perceived usefulness had a large significant effect on the intention to adopt technology and its influence was complemented by the perceived enjoyment.

In previous IT research on practical systems, Deng et al.[24], Kim \& Hwang[25], Van der Heijden[26] and Wakefield \& Whitten[27], reported that perceived enjoyment is significant in influencing IT continuance intention for specific purposes as well as perceived usefulness. The findings show that perceived usefulness is also significant in influencing IT continuance intention for functional purposes. From this results, Khedhaouriaet al.[28]recommended that the integration of perceived enjoyment is significantly important in an everyday life context.

\subsection{Use and Gratification Theory}

The Uses and Gratifications Theory is a popular approach to understand mass communication. It focuses on the consumers by asking "what people do with media". Mehrad \& Tajer[29] explain the origin and the development of this theory in their study. The uses and gratifications are divided into five categories related to five groups of human needs [30] as shown in Table 2.

\begin{tabular}{|c|c|}
\hline Groups & \begin{tabular}{|c|} 
Explanations \\
\end{tabular} \\
\hline Cognitive needs & $\begin{array}{l}\text { acquiring information, knowledge, } \\
\text { understanding our social environment, } \\
\text { curiosity, exploration }\end{array}$ \\
\hline Affective needs & $\begin{array}{l}\text { aesthetic and emotional experiences, } \\
\text { pleasure }\end{array}$ \\
\hline Personal identity & $\begin{array}{l}\text { self-confidence, personal stability, } \\
\text { integrity, social status, the need for self- } \\
\text { respect }\end{array}$ \\
\hline $\begin{array}{l}\text { Integration and } \\
\text { social interaction }\end{array}$ & $\begin{array}{l}\text { family relations and friendship, } \\
\text { connection with the outside } \\
\text { need for affiliation }\end{array}$ \\
\hline Escapism & $\begin{array}{l}\text { the need to escape, tension release, } \\
\text { shifting attention from unpleasant to } \\
\text { pleasant }\end{array}$ \\
\hline
\end{tabular}

Table 2: Five Categories of Uses and Gratification Theory 
Rubin [31]suggested eight different factors for consuming any media which is 1) To pass the time, 2) Companionship, 3) Escape, 4) Enjoyment, 5) Social interaction, 6) Relaxation, 7) Information and 8) Excitement.

Whiting and Williams [32] stated that SNSs can produce cognitive needs by allowing users to obtain sales, deals and product information related to user preference, occasions and commerce. Users can educate themselves to learn new things by using social media exploration and find the step by step manual to assist them.

Mas'od et al.[5]discussed that Facebook features allow users to browse contents through liking and following user accounts. As a result of doing this, cognitive gratification on Facebook occurs by gaining information and tracking the similar interests and hobbies within their friends [33].Sharing digital photos on social media is one of the trending practices nowadays because the image can create perceived information to human mind. It is a perfect way to provide understanding the information of specific activities in a more comprehendible manner. Malik et al.[34]stated the Facebook-based photo sharing related activities are the most significant to provide necessary information to share news and ideas by providing generous information and mind comfortable instead of texting which is much more complicated to digest.

\subsection{Behavioural Intention Model}

Behaviouralintention (BI) is frequently foreseen in multi-attribute models[35]which focuses on users' motives regarding the various attributes of a technology. According to Mamman et al.[36], intention can be defined as "howhard persons are willing to try and how much determinations they are planning to use towards performing a behaviour". Meanwhile, behavioural intention refers to "a person's subjective probability that he will perform some behaviours" [37].

IT behavioural research constituted that behavioural intention is the prima factor of usage behaviour[38]. Thebehavioural intention model has a function of three independent predecessor factors namely consumers attitude, subjective norm and perceived behavioural control.

\section{RESEARCH MODEL AND HYPOTHESES DEVELOPMENT}

In this study, constructs from the UTAUT model areadopted and extended by incorporating the constructs of perceived enjoyment and cognitive gratification inidentifying factors that influence users'behavioural intentions to use Facebook to learn how to grow plants and get involved with the home garden project during COVID-19 Pandemic. Previous studies[39],[40],[41] found that increasing the number of external variables can enhance this model's ability to predict the acceptance of the system.

According to Venkatesh [16], performance expectancy, effort expectancy, and social influence were theorized and found to influence behavioural intention to use technology.Kabra et al.[39] found that performance expectancy and effort expectancyhave a positive linked withbehavioural intention. Recent studies have identified performance expectancy and social influence have a positive effect on behavioural intention as in [42], [43]. Besides, Mouakket [44]finds that enjoyment positively influences user's continuance intention toward SNS andBurešová[4] identified information sharing, socializing,and entertainment influence users to use Facebook.

In this study, constructions of performance expectancy, effort expectancy, facilitating conditions, perceived enjoyment, and cognitive gratification are used as Independent Variables, whereas a behavioural intention is a Dependent Variable. Figure 2 shows the proposed research model.

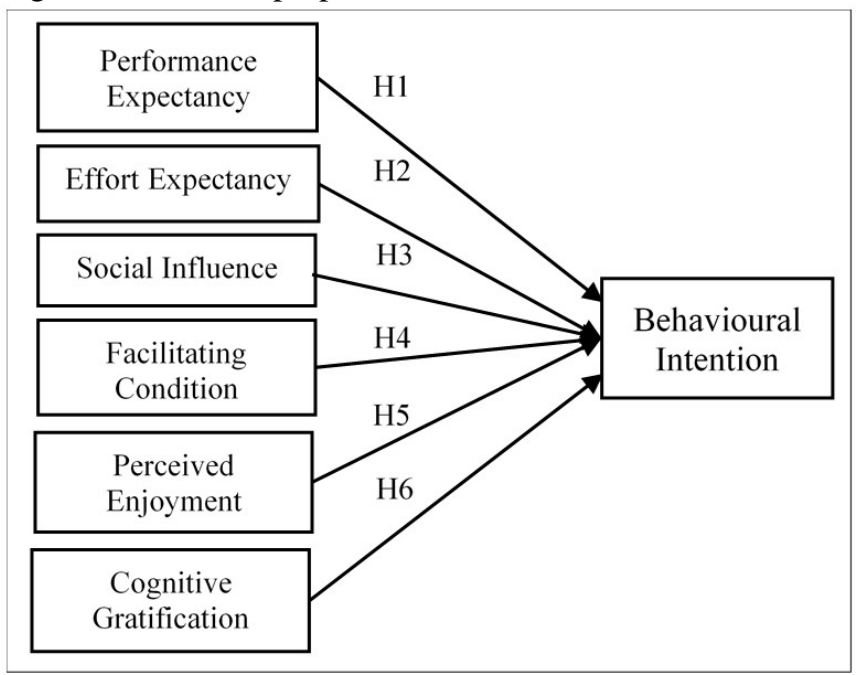

Figure 2: Research Model and hypotheses

\section{A. Performance Expectancy}

In the context of users using Facebook for gardening discussion, performance expectancy means that a Facebook user believes that using Facebook to participate in gardening discussion will help them to learn on how to grow plants and get involved with the home garden project during COVID-19 Pandemic.

Hypothesis 1: Performance Expectancy has a significant influence on the BIs of people to participate in the gardening discussions via Facebook

\section{B. Effort Expectancy}

Effort Expectancy means "the degree of ease associated with the use of the system"[16]. In this study, if users believe it is easy to use Facebook then the chances of gaining more intentions to get involved in gardening discussions will be increased. 
Hypothesis 2: Effort Expectancy has a significant influence on the BIs of people to participate in the gardening discussions via Facebook.

\section{Social Influence}

Venkatesh \& Davis [45] introduced the Social Influence constructs in TAM2, andlater it was included in UTAUT Model [16]. Social Influence is defined as "the extent to which a person perceives that important others to believe he or she should use a new system"[16]. According to Ngai et al.[46], social influence is an essential factor driving the intention to use, and it has been used widely in social media research. Thus, if Facebook users feel that many of their friends are participating in gardening discussions on Facebook, they are more likely to have the intention to participate in gardening discussions through Facebook.

Hypothesis 3: Social Influence has a significant influence on the BIs of people to participate in gardening discussions via Facebook.

\section{D.Facilitating Conditions}

Facilitating conditions is defined as "the degree to which an individual believes that an organizational and technical infrastructure exists to exists to support use of the system"[16].Therefore, in this study,facilitating conditions include technological conditions (e.g., Internet or Smartphone access to Facebook) and knowledge on using Facebook.

Hypothesis 4: Facilitating Conditionshas a significant influence on the BIs of people to participate in gardening discussions via Facebook.

\section{E. Perceived Enjoyment}

According to Davis et al.[23], "enjoyment is an intrinsic motivation that describes how an individual perceives something to be enjoyable regardless of the anticipated consequences". In this study, if users believe it is fun to use Facebook, it can influence users' intention to participate in gardening discussions through Facebook.

Hypothesis 5: Perceived Enjoyment has a significant influence on the BIs of people to participate in the gardening discussions via Facebook.

\section{F. Cognitive Gratification}

The Uses and Gratification Theory has been widely used in previous studies related to social media[34],[33],[47],[48]. One of the reasons people use social media is for cognitive gratification, where they can easily search and share information, increase their knowledge and understand the social environment.

Hypothesis 6: Cognitive Gratification has a significant influence on the BIs of people to participate in gardening discussions via Facebook.
All the above variables are shown in Table 3 with their definitions and sources.

Table 3: Constructs and definitions

\begin{tabular}{|c|c|c|c|}
\hline Variables & Definition & Origin & $\begin{array}{c}\text { Referred } \\
\text { Articles }\end{array}$ \\
\hline $\begin{array}{l}\text { Performance } \\
\text { Expectancy }\end{array}$ & $\begin{array}{l}\text { "The extent to which an } \\
\text { individual believes that } \\
\text { using an information } \\
\text { system will help him or } \\
\text { her to attain benefits in } \\
\text { job performance." }\end{array}$ & [16] & $\begin{array}{l}\text { [40],[49], } \\
{[50]}\end{array}$ \\
\hline $\begin{array}{l}\text { Effort } \\
\text { Expectancy }\end{array}$ & $\begin{array}{l}\text { "The degree of ease } \\
\text { associated with the use } \\
\text { of system." }\end{array}$ & [16] & $\begin{array}{l}{[40],[49],} \\
{[50]}\end{array}$ \\
\hline $\begin{array}{l}\text { Social } \\
\text { Influence }\end{array}$ & $\begin{array}{l}\text { "The extent to which a } \\
\text { person perceives that } \\
\text { important others to } \\
\text { believe he or she should } \\
\text { use an information } \\
\text { system." }\end{array}$ & [16] & $\begin{array}{l}{[11],[40],} \\
{[45],[49],} \\
{[50],[51]}\end{array}$ \\
\hline $\begin{array}{l}\text { Facilitating } \\
\text { Conditions }\end{array}$ & $\begin{array}{l}\text { "The degree to which an } \\
\text { individual believes that } \\
\text { an organizational and } \\
\text { technical infrastructure } \\
\text { exists tosupport use of } \\
\text { the system." }\end{array}$ & [16] & $\begin{array}{l}{[40],[49],} \\
{[50]}\end{array}$ \\
\hline $\begin{array}{l}\text { Perceived } \\
\text { Enjoyment }\end{array}$ & $\begin{array}{l}\text { "The extent to which the } \\
\text { activity of using a } \\
\text { specific system is } \\
\text { perceived to be } \\
\text { enjoyable in its own } \\
\text { right, aside from any } \\
\text { performance." }\end{array}$ & [23] & $\begin{array}{l}{[33],[40],} \\
{[44],[52],} \\
{[53],[54],} \\
{[55]}\end{array}$ \\
\hline $\begin{array}{l}\text { Cognitive } \\
\text { Gratification }\end{array}$ & $\begin{array}{l}\text { "Acquiring information, } \\
\text { knowledge, } \\
\text { understanding our social } \\
\text { environment, } \\
\text { curiosity, exploration." }\end{array}$ & [30] & $\begin{array}{l}{[4],[33],} \\
{[47],}\end{array}$ \\
\hline
\end{tabular}

\section{CONCLUSION}

There have been limited studies on media influence of both mass media and social media in the context of encouraging people to involve with the home garden project. The theoretical implications of this study will offer a conceptual basis for the understanding of media-related behaviours or consequences on the nature of individual users with different purposes. Therefore, we used UTAUT model to predict the factors of influencing media social mainly Facebook user's behaviour to involve with the home garden project during $\mathrm{MCO}$. We utilized the existing factors, which are performance expectancy, effort expectancy, social influence and facilitating condition together with two new factors; perceived enjoyment and cognitive gratification to predict primary factors of influencing Facebook user's behavior to involve with the home garden project during MCO.

Considering this research is still ongoing, future work will focus on the empirical validation to test and validate the proposed model. This proposed model may provide a guideline to develop a system that can promote peoples' 
intention to learn how to grow plants and get involved with a home garden project.

\section{ACKNOWLEDGEMENT}

We would like to express our sincere thanks towards UiTM Cawangan Melaka for the generousfundingthrough Teja Internal Grant numbered GDT2020-30 which allowed us to conduct this research.We also would like to express our gratitude to all people who were directly orindirectly involved in this study.

\section{REFERENCES}

1. A. Sofo and A. Sofo. Converting home spaces into food gardens at the time of covid-19 quarantine: all the benefits of plants in this difficult and unprecedented period, in Hum. Ecol., 2020, doi: 10.1007/s10745-020-00147-3.

2. M. B. Horzum and E. Demirhan. The role of chronotype on facebook usage aims and attitudes towards facebook and its features, in Comput. Human Behav., vol. 73, pp. 125-131, 2017, doi: https://doi.org/10.1016/j.chb.2017.03.038.

3. K. F. Hew. Students' and teachers' use of facebook, in Comput. Human Behav., vol. 27, no. 2, pp. 662-676, 2011, doi: https://doi.org/10.1016/j.chb.2010.11.020.

4. J. Burešová. Why people use facebook: Analysis of factors influencing users in the Czech Republic, in Proc. 28th Int. Bus. Inf. Manag. Assoc. Conf. - Vis. 2020 Innov. Manag. Dev. Sustain. Compet. Econ. Growth, pp. 470-481, Dec. 2016.

5. A. Mas'od, U. N. Idris, Z. Sulaiman, and T. A. Chin. The influence of facebook features and activities on consumers' purchase intention, in 2019 6th International Conference on Research and Innovation in Information Systems (ICRIIS), 2019, pp. 1-6, doi: 10.1109/ICRIIS48246.2019.9073639.

6. M. Chung. Not just numbers: The role of social media metrics in online news evaluations, in Comput. Human Behav., vol. 75, pp. 949-957, 2017.

7. S. Messing and S. J. Westwood. Selective exposure in the age of social media: Endorsements trump partisan source affiliation when selecting news online, in Communic. Res., vol. 41, no. 8, pp. 1042-1063, 2014.

8. J. Fox, C. Cruz, and J. Y. Lee. Perpetuating online sexism offline: Anonymity, interactivity, and the effects of sexist hashtags on social media, in Comput. Human Behav., vol. 52, pp. 436-442, 2015.

9. J. Richard and S. Guppy. Facebook: Investigating the influence on consumer purchase intention, in Asian J. Bus. Res., vol. 4, pp. 1-15, Dec. 2014, doi: 10.14707/ajbr.140006.

10. M. Dehghani and M. Tumer, A research on effectiveness of facebook advertising on enhancing purchase intention of consumers, in Comput. Human Behav., vol. 49, pp. 597-600, 2015.

11. V. Lamanauskas, C. Pribeanu, and D. D. Iordache. Exploring the relationship between social influence and addiction in facebook use: a comparative study, in The 16th International Conference on Informatics in Economy (IE2017), Education, Research \& Business Technologies, 04-07 May 2017, Bucharest, Romania: conference proceedings, 2017, pp. 146-151.

12. G. Pollard, P. Roetman, J. Ward, B. Chiera, and E. Mantziori. Beyond productivity: Considering the health, social value and happiness of home and community food gardens, Urban Sci., vol. 2, no. 4, p. 97, 2018.

13. M. Soga, D. T. C. Cox, Y. Yamaura, K. J. Gaston, K. Kurisu, and K. Hanaki. Health benefits of urban allotment gardening: Improved physical and psychological well-being and social integration,inInt. J. Environ. Res. Public Health, 2017, doi: 10.3390/ijerph14010071.

14. C. J. Wood, J. Pretty, and M. Griffin. A case-control study of the health and well-being benefits of allotment gardening, in J. Public Heal. (United Kingdom), 2016, doi: 10.1093/pubmed/fdv146.

15. M. Soga, K. J. Gaston, and Y. Yamaura. Gardening is beneficial for health: A meta-analysis, in Preventive Medicine Reports. 2017, doi: 10.1016/j.pmedr.2016.11.007.

16. V. Venkatesh, M. G. Morris, G. B. Davis, and F. D. Davis. User Acceptance of Information Technology: Toward a Unified View, MIS Q., vol. 27, pp. 425-478, 2003, doi: 10.2307/30036540.

17. M. D. Williams, N. P. Rana, and Y. K. Dwivedi. The unified theory of acceptance and use of technology (UTAUT): a literature review, in J. Enterp. Inf. Manag., vol. 28, no. 3, pp. 443-488, Apr. 2015, doi: 10.1108/JEIM-09-2014-0088.

18. M. Nüttgens, A. Gadatsch, K. Kautz, I. Schirmer, and N. Blinn. Governance and Sustainability in Information Systems. Managing the transfer and diffusion of IT, vol. 366. Berlin, Heidelberg: Springer Berlin Heidelberg, 2011.

19. M. K. O. Lee, C. M. K. Cheung, and Z. Chen. Acceptance of internet-based learning medium: The role of extrinsic and intrinsic motivation, in Inf. Manag., 2005, doi: 10.1016/j.im.2003.10.007.

20. F. D. Davis, R. P. Bagozzi, and P. R. Warshaw. User acceptance of computer technology: a comparison of two theoretical models, in Manage. Sci., vol. 35, no. 8, pp. 982-1003, 1989.

21. H. C. Kelman. Compliance, identification, and internalization three processes of attitude change, in J. Conflict Resolut., 1958, doi: 10.1177/002200275800200106.

22. R. P. Bagozzi and K.-H. Lee. Multiple routes for social influence: The role of compliance, internalization, and social identity, in Soc. Psychol. Q., pp. 226-247, 2002.

23. F. D. Davis, R. P. Bagozzi, and P. R. Warshaw. Extrinsic and intrinsic motivation to use computers in the workplace, in J. Appl. Soc. Psychol., vol. 22, no. 14, pp. 1111-1132, 1992.

24. L. Deng, D. E. Turner, R. Gehling, and B. Prince. User experience, satisfaction, and continual usage intention of IT, in Eur. J. Inf. Syst., 2010, doi: 
10.1057/ejis.2009.50.

25. D. J. Kim and Y. Hwang. A study of mobile internet usage from utilitarian and hedonic user tendency perspectives, in Association for Information Systems 12th Americas Conference On Information Systems, AMCIS 2006, 2006.

26. H. Van Der Heijden. User acceptance of hedonic information systems, MIS Q. Manag. Inf. Syst., 2004, doi: $10.2307 / 25148660$.

27. R. L. Wakefield and D. Whitten. Mobile computing: a user study on hedonic/utilitarian mobile device usage, in Eur. J. Inf. Syst., vol. 15, no. 3, pp. 292-300, 2006, doi: 10.1057/palgrave.ejis.3000619.

28. A. Khedhaouria and A. Beldi. Perceived Enjoyment and the effect of gender on continuance intention for mobile internet services, in Int. J. Technol. Hum. Interact., vol. 10, no. 2, pp. 1-20, Apr. 2014, doi: 10.4018/ijthi.2014040101.

29. J. Mehrad and P. Tajer. Uses and Gratification theory in connection with knowledge and information science: A proposed conceptual model, vol. 14, pp. 1-14, Jan. 2016.

30. E. Katz, H. Haas, and M. Gurevitch. On the use of the mass media for important things,inAm. Sociol. Rev., pp. 164-181, 1973.

31. A. M. Rubin. An examination of television viewing motivations, in Communic. Res., 1981, doi: 10.1177/009365028100800201.

32. A. Whiting and D. Williams. Why people use social media: a uses and gratifications approach, Qual. Mark. Res. An Int. J., 2013.

33. I. Tanta, M. Mihovilović, and Z. Sablić. Uses and Gratification theory - Why adolescents use facebook?,MedijskaIstraz., 2014.

34. A. Malik, A. Dhir, and M. Nieminen. Uses and Gratifications of digital photo sharing on Facebook, in Telemat. Informatics, vol. 33, no. 1, pp. 129-138, 2016, doi: https://doi.org/10.1016/j.tele.2015.06.009.

35. E. B. Swanson. Information system implementation: Bridging the gap between design and utilization. McGraw-Hill/Irwin, 1988.

36. M. Mamman, A. F. Ogunbado, and A. S. Abu-Bakr. Factors influencing customer's behavioral intention to adopt islamic banking in northern Nigeria: A proposed framework, in IOSR J. Econ. Financ., pp. 51-55, 2016

37. M. Fishbein and I. Ajzen. Belief, attitude, intention and behavior: An introduction to theory and research. 1975.

38. T. H. Kwon and R. W. Zmud. Unifying the fragmented models of information systems implementation, in Critical issues in information systems research, 1987, pp. 227-251.

39. G. Kabra, A. Ramesh, P. Akhtar, and M. K. Dash. Understanding behavioural intention to use information technology: Insights from humanitarian practitioners, in Telemat. Informatics, vol. 34, no. 7, pp. 1250-1261, 2017 , doi: https://doi.org/10.1016/j.tele.2017.05.010.

40. T. Escobar-Rodríguez, E. Carvajal-Trujillo, and P.
Monge-Lozano. Factors that influence the perceived advantages and relevance of Facebook as a learning tool: An extension of the UTAUT, in Australias. J. Educ. Technol., vol. 30, no. 2, 2014.

41. S. Meth, K. Y. Lee, and S.-B. Yang. Factors Influencing Facebook Users' Political Participation: Investigating the Cambodian Case.," in PACIS, 2015, p. 44.

42. E. S. Panjaitan and R. Budiarto. The role of intelligence in e-learning usage: An extension of UTAUT model, in Int. J. Adv. Trends Comput. Sci. Eng., 2019, doi: 10.30534/ijatcse/2019/79862019.

43. N. Legowo and K. Vitalli, Factors influencing the adoption of internet banking system using utaut combined ttf at private bank indonesia, in Int. J. Adv. Trends Comput. Sci. Eng., 2020, doi: 10.30534/ijatcse/2020/08912020.

44. S. Mouakket. Factors influencing continuance intention to use social network sites: The facebook case, in Comput. Human Behav., vol. 53, pp. 102-110, 2015, doi: https://doi.org/10.1016/j.chb.2015.06.045.

45. V. Venkatesh and F. D. Davis. A Theoretical Extension of the technology acceptance model: four longitudinal field studies, in Manage. Sci., vol. 46, no. 2, pp. 186-204, 2000, doi: 10.1287/mnsc.46.2.186.11926.

46. E. W. T. Ngai, S. S. C. Tao, and K. K. L. Moon. Social media research: Theories, constructs, and conceptual frameworks, in Int. J. Inf. Manage., vol. 35, no. 1, pp. 33-44, 2015, doi: 10.1016/j.ijinfomgt.2014.09.004.

47. Y. W. Ha, J. Kim, C. F. Libaque-Saenz, Y. Chang, and M. C. Park. Use and gratifications of mobile SNSs: Facebook and KakaoTalk in Korea, in Telemat. Informatics, 2015, doi: 10.1016/j.tele.2014.10.006.

48. P. Ifinedo. Applying uses and gratifications theory and social influence processes to understand students' pervasive adoption of social networking sites: Perspectives from the Americas, in Int. J. Inf. Manage., vol. 36, no. 2, pp. 192-206, 2016, doi: https://doi.org/10.1016/j.ijinfomgt.2015.11.007.

49. F. J. Rondan-Cataluña, J. Arenas-Gaitán, and P. E. Ramírez-Correa. A comparison of the different versions of popular technology acceptance models: A non-linear perspective, Kybernetes, vol. 44, no. 5, pp. 788-805, 2015.

50. A. Raman and $H$. Lateh. Using facebook as a collaborative and communicative tool, in Mediterr. $J$. Soc. Sci., vol. 6, no. 2 S1, pp. 286-292, 2015.

51. I. Ajzen. From intentions to actions: A Theory of Planned Behavior, in Action Control, 1985, pp. 11-39.

52. J. Bourgonjon, M. Valcke, R. Soetaert, and T. Schellens. Students' perceptions about the use of video games in the classroom, in Comput. Educ., vol. 54, no. 4, pp. 1145-1156, May 2010, doi: 10.1016/j.compedu.2009.10.022.

53. L. Amadu, S. S. Muhammad, A. S. Mohammed, G. Owusu, and S. Lukman. Using technology acceptance model to measure the ese of social media for collaborative learning in Ghana, in JOTSE, vol. 8, no. 4, pp. 321-336, 2018.

54. Y. Song and J. Han. Is enjoyment important? An empirical research on the impact of perceive 
enjoyment on adoption of new technology, in 2009 International conference on information management, innovation management and industrial engineering, 2009, vol. 4, pp. 511-514.

55. R. Rupak, R. Greg, Y. Jei, and J. Ben. Technology acceptance model (TAM) and social media usage: an empirical study on Facebook, in J. Enterp. Inf. Manag., vol. 27, no. 1, pp. 6-30, Jan. 2014, doi: 10.1108/JEIM-04-2012-0011. 